\title{
REFLEXÕES SOBRE A SUBJETIVIDADE NA COLONIZAÇÃO
}

\author{
Claudine Haroche*
}

A atividade comunitária (...) exprime-se, de modo geral, pela segregação e desprezo, ou , ao contrário, ela se manifesta pela crença supersticiosa daqueles que, de uma maneira espantosa, são de uma outra espécie. O indivíduo diferente (...) é ,de todos os modos, desprezado como tal, ou vice-versa, ele é adorado de modo supersticioso, permanecendo, constantemente, em estado de superioridade. Todavia, a repulsa é a atitude primária e normal. $^{1}$

Em 1911, faltavam apenas alguns enunciados a Max Weber para o esboço de uma sociologia do clima social e político, para evocar as questões essenciais que tratavam sobre a nação, o nacionalismo, as comunidades e as raças. Weber trata, primeiramente, do fundamento da existência da comunidade, de que ela seja "subjetivamente testada" como uma característica comum.”A seguir, ele dá destaque ao caráter paradoxal, intenso e ameaçador das relações entre as comunidades.

O pertencimento à comunidade supõe e desenvolve um sentimento específico de atração e implica, ao mesmo tempo, a rejeição, a estigmatização, a exclusão do outro, daquele que é então definido como sendo estrangeiro, o que provoca o sentimento de humilhação daquele que é rejeitado².

O sentimento de humilhação que, implícita ou explicitamente, voluntária ou involuntariamente, consciente ou inconscientemente está no centro da atividade comunitária, aparece como a face obscura dos sentimentos de pertencimento: sentindo de modo subjetivo, ela revela também com intensidade a condição de não pertença, de exclusão: ela é a conseqüência dos processos de segregação, de desprezo, de rejeição que suscitarão, inevitavelmente, a seguir, a humilhação.

A colonização permite apreender os processos nesta intensidade: a situação exacerba, com efeito, o sentimento de pertença, da mesma forma que o sentimento de humilhação. ${ }^{3}$ Ao provocar a falta, a perda, a negação do valor de si, o sentimento de humilhação, toca fundamentalmente nas diferentes formas de colonização, na propriedade de si, na própria condição de ser humano. ${ }^{4}$

\footnotetext{
* Diretora de Pesquisa do CNRS - Paris. A Autora agradece a Yves Déloye por suas observações críticas e suas numerosas sugestões.

${ }^{1}$ M. Weber (1956). Capítulo IV, As relações comunitárias étnicas. In: Economie et societé.

${ }^{2}$ G. Simmel. Excursus sur l'etranger. Sociologie (1905), Paris, Ed. PUF, 1999. GOFFMAN, E. Stigmates (1963), Paris, Ed. Minuit, 1975.

${ }^{3}$ G. Balandier (1951) Cahiers Internationaux de Sociologie, e recentemente: Civilisés Dit-on (2003), em particular a situação colonial; noção antiga, realidade nova. É a intensidade da relação colonial que havia sido apreendida desde 1950. ${ }^{\circ}$ Mannoni em "Psicologia da Colonização", republicada sob o título "Prospero e Caliban. Psicologia da Colonização” (1984) sublinha a importância teórica do estudo de uma situação colonial em seus aspectos gerais (id.,p.29) e observa "se há um domínio onde os fatos (de racismo) podem ser observados facilmente, é no domínio colonial: uma situação colonial, com efeito, é caracterizada pelo fato de que a diferença de estrutura das personalidades presentes é grande, maior do que em qualquer outra situação" (id.,p.35).

${ }^{4} \mathrm{Cl}$. Haroche. Observações sobre as incertezas e as ambigüidades do direito à dignidade. In: KOUBI, G. (1996) Le Préambule de laConstitution de 1946. Antinomies juridiques et contradictions politiques. Cl.
} 
Agregamos, aqui, uma abordagem um pouco genérica, análoga àquela de Albert Memmi com relação às atitudes, às condutas, às disposições psicológicas unindo o colonizado e o colonizador: o que é "vivido subjetivamente" na relação colonial deve ser reportado não somente a um dado contexto - cultural, geográfico, social, étnico, político, mas também a um contexto humano geral que reenvie a uma concepção fundamental do humano. ${ }^{5}$ As culturas, não obstante sua diversidade, têm em comum a questão do humano, o modo de respeitá-lo, de tratá-lo, de não ultrapassar certos limites para além dos quais eles sejam confrontados ao desumano. ${ }^{6}$

Os fatos visíveis ou invisíveis, dizíveis ou indizíveis que provocam a humilhação, os mecanismos que a conduzem, variam segundo os momentos, os sistemas, as condições, mas a humilhação comportará um núcleo irredutível, de um lado. As colonizações são mais ou menos violentas, mais ou menos brutais, abertas ou insidiosas, extensas ou restritas, mas todas reenviam à ausência, à privação, até mesmo à negação da autonomia e do valor do próprio colonizado, retornando, assim, à humilhação. Todas arrebatam, deste modo, a sensação, senão é o sentimento, e, em conseqüência, a consciência da opressão, da alienação, da servidão, da dependência, e, enfim, da impotência.

Weber discerne nos funcionamentos comunitários uma oposição entre desprezo, rejeição, estigmatização, repulsa, de um lado, e crença, mitificação, atração, fascinação e veneração por outro lado.

Colocando em destaque o medo, o horror, o terror experimentado diante da diferença, Weber pressente, deste modo, que o estudo das relações de atração ou de repulsão entre diferentes comunidades étnicas não estaria, no momento, senão em seu começo. $^{7}$

Ele atribui essa rejeição à incompreensão, ao fato de que "o elemento muitas vezes decisivo é que o sentido subjetivo do costume divergente não é apreendido porque não possuímos uma chave para tal”. ${ }^{8}$

O indivíduo outro será, deste modo, percebido como uma diferença ameaçadora, revelando um grande afastamento, muitas vezes radical e ininteligível.

Weber coloca-se, entretanto, em posição de defesa "todas as repulsas não podem ser atribuídas à ausência de uma compreensão”. ${ }^{9}$ Certas repulsas colocarão em foco formas de dominação que implicam, ao revés, o excesso de compreensão, de proximidade, a intrusão do outro, a fusão.

\footnotetext{
Haroche (2001) .Proprieté privé, proprieté sociale, proprieté de soi. Entretiens sur la construction de l'individu moderne.

5 o Mannoni observa que se trata de "fenômenos que se manifestam em uma situação colonial e da maneira, através da qual, as colônias reagem tanto mais que os colonizados", colocando em destaque, então que "este domínio de pesquisa é quase inexplorado”. Para um estudo recente, entre outros,A. RUSCIO (2002). Le Credo de l'Homme Blanc

${ }^{6}$ A MEMMI (1957) Portait du Colonisé. (Préfácio de Jean Paul-Sartre. LEVI-STRAUSS (1951), C. Race et Histoire; em particular, História Estacionária e História Cumulativa e Etnocentrismo. H. ARENDT (1951), L'imperialisme. In: Les Origines du Totalitarisme; J. CONRAD ( 1902), Au Coeur des Ténèbres, Paris, 2003; P. LEVI (1958) Si C’est un Homme, Paris, 1967; S. FREUD (1930) Malaise dans la Culture, Paris, 1995.

${ }^{7}$ WEBER, Economie et Societé. (nota 1, supra-citada, p.125.

${ }^{8}$ Ibid., p.127. Ver igualmente TONNIES (1887). Community and Society, New York, 2002. C. LEVISTRAUSS, Race et Histoire, supra-citada.

${ }^{9}$ M. WEBER, nota supra-citada, p.127.
} 
Consciente do caráter geral de sua observação, ele coloca que "toda pesquisa propriamente sociológica deveria analisar os conceitos de uma maneira incomparavelmente mais fina do que fazemos aqui, onde nossa meta é limitada."

Parece-nos que é precisamente essa fineza que Arendt e Memmi testemunharam ao estudarem as atitudes, o lugar subjetivo dos administradores britânicos e dos colonizadores de modo geral.

\section{A ARROGÂNCIA, UM ELO ENTRE HUMILHAÇÃO E DOMINAÇÃO}

Prolongando alguns dos elementos dispensados por Weber, quanto à importância crucial daquilo que é experimentado subjetivamente, seja a atração ou a repulsão, e transpondo-os, Arendt irá oferecer um quadro geral da evolução histórica, política e psicológica desses funcionamentos no contexto do nacionalismo, da expansão imperialista e do nacionalismo tribal. Arendt encarrega-se, deste modo, de elucidar as origens e os efeitos da repulsa evocada por Weber, antecipando que a raça e a burocracia constituem respostas - no contexto do nacionalismo expansionista - ao terror experimentado face às diferenças percebidas como aterrorizantes e insuperáveis.

Ela atualiza os fundamentos da raça, discerne na raça uma explicação "para a existência de alguns seres que pertencem à Europa ou ao mundo civilizado, que não se poderia compreender, e cuja natureza parece tão terrificante e tão humilhante aos olhos dos imigrantes que eles não poderiam imaginar pertencer ao gênero humano por muito mais tempo."10

Arendt entrevê na burocracia uma resposta ao medo da alteridade e, igualmente, os meios políticos inéditos, as formas de governo, pelo viés da administração, que visam a impor organização política e dominação social às populações estrangeiras - e assim colonizadas - durante o curso dos primeiros decênios do imperialismo.

A propósito da raça descoberta na África do Sul, Arendt observa que ela "representava, na origem, uma reação semi-consciente face aos povos que produziam terror e medo ao homem europeu." Sobre a burocracia instaurada na Algéria, no Egito e na Índia, ela escreve que " foi graças à seqüela desta administração que os europeus tinham ensaiado governar os povos estrangeiros, e que não podiam, decididamente, ver que os povos inferiores tinham grande necessidade de sua proteção. ${ }^{11}$

Arendt irá ligar-se à psicologia que se instaura, preside e apreende esta dinâmica entre raças superiores e inferiores; de uma alteridade vivida como radical que, fatalmente, provoca um sentimento de humilhação profunda: a humilhação de se ser considerado indivíduo de menor qualidade; para além, um indivíduo sem qualidade, sem especificidade, sem originalidade, singularidade ou personalidade. Um indivíduo inferior.

Ela detêm-se também nas maneiras de ser e de sentir dos colonizadores. Observando a personalidade destes, ela fornece uma explicação profunda dos efeitos psíquicos, da

\footnotetext{
${ }^{10}$ ARENDT, H. L’imperialisme.. Nota 6, supra-citada. Sobre estas questões ver Marion Brephol, “Arrogância e Isolamento na Política Colonial de Carl Peters.” In: NAXARA, Márcia, MARSON, Isabel \& BRESCIANI, Maria Stella. (2005) Humilhação: sentimentos, gestos e palavras. Ver também “ e Imperialismo: o imaginoso Carl Peters. In: Anais do XXII Simpósio Nacional de História, 2003.

${ }^{11}$ Ibid., p.145.
} 
transformação psíquica que a relação colonial faz o colonizado suportar no imperialismo, na política expansionista. ${ }^{13}$

\subsection{A Arrogância da Dominação}

Arendt insiste em tratar, de forma particular, da arrogância totalmente nova dos administradores, explicando esta arrogância pelo medo da diferença, da alteridade, da incompreensão, da distância; mas ela observa logo que esses administradores não se detêm pelo medo, eles o ultrapassam e pretendem exprimir um sentimento de superioridade diante das populações que eles têm como “atrasadas” e das raças tidas como “inferiores.”Ela se interroga sobre as origens e os efeitos da arrogância, fundamentalmente sobre o fato de que o nacionalismo tribal autoriza e encoraja os sentimentos de superioridade e, ao revés, de inferioridade, exacerbando assim a humilhação. Arendt fala, deste modo, dos efeitos da "nova consciência imperialista" que se define pelo sentimento de uma superioridade fundamental e não simplesmente temporária, de homens sobre homens, de raças superiores sobre raças "inferiores." 14

Em nome da "necessidade” de dominar os povos e , através dela, oprimi-los, a arrogância irá constituir a atitude característica dos administradores, dos burocratas e, ao mesmo tempo, para além, do modo de governar do nacionalismo expansionista. É preciso ver na arrogância a expressão de uma forma específica de propriedade de si: o fato de arrogar-se às vezes com uma violência implacável - a propriedade de si, a propriedade do outro; uma atitude, uma maneira de ser, mas também um modo de governar, um modo de dominação que irá inevitavelmente conduzir à humilhação.

Arendt oferece, então, uma descrição psicológica precisa do colonizador que impõe uma humilhação intensa e incessante ao colonizado, aos povos que são julgados como inferiores, e até mesmo inexistentes. Ela se interroga, assim, sobre a natureza desta distância na qual ela percebe “ uma curiosa mistura de arrogância e de respeito", "distinguindo a arrogância do "respeito que habita essa hibridez, totalmente negativa e, portanto, incapaz de engendrar um novo modelo necessário aos povos chamados a viver junto, não chegando a controlar a cruel e despótica administração imperialista." ${ }^{215}$

Os administradores das colônias são arrogantes, mas antes de tudo são distantes; isso não impede a instauração de relações às vezes íntimas, paternalistas e carregadas de desdém. ${ }^{16}$

Arendt dá destaque à distância observada por administradores que

em virtude de seu sincero respeito pelos nativos como povo, e mesmo, em certos casos, de seu amor por eles... não pensam que eles sejam ou serão capazes, um dia, de governar-se a si próprios sem vigilância. ${ }^{17}$

\footnotetext{
${ }^{13}$ Arendt lembra, deste modo, que na "Alemanha, onde o conflito entre a nobreza e a classe média ascendente não é jamais regrado na cena política, o culto à personalidade é desenvolvido como o único meio de obter, pelo menos, uma espécie de emancipação social.” (ibid., p.86)

${ }^{14}$ Ibid., p.22.

${ }^{15}$ Ibid., p.23.

${ }^{16}$ A L. Stoler (2002), Carnal knowledge and imperial power. Race and the intimate in colonial rule.

${ }^{17}$ H. Arendt, nota 6, supra-citada, p.22.
} 
Convém refletir, aqui, sobre a natureza da diferença e até mesmo da alteridade: a que conduzem? Como se traduzem? A que se referem? Em que consiste a distância que instauram? Convém também avaliar os efeitos desses comportamentos sobre os indígenas que só podiam tirar uma conclusão: "que foram excluídos e separados de todo o resto da humanidade." ${ }^{18}$

$\mathrm{O}$ administrador que se considera humano, plenamente humano, sabe governar-se. Ele domina suas condutas, suas pulsões - ele pode e deve, deste modo, governar o outro que, em virtude de suas faltas, suas carências, suas falhas, sua inaptidão e incapacidade de se controlar é considerado pelo colonizador como sendo dotado, por tais razões, de signos tangíveis de sua inferioridade. ${ }^{19}$

O colonizado é um impulsivo que é preciso conter, vigiar, para, em primeiro lugar ter proteção, e, em segundo lugar, protege-lo de si mesmo, é preciso tê-lo à distância, domesticá-lo para colonizar....até mesmo combate-lo e extermina-lo, se ele se torna perigoso, ameaçador, assustador e, assim, desumano.

Focalizando a psicologia dos administradores ingleses, personificada pela arrogância, Arendt observa que desta arrogância e indiferença resulta o isolamento. Ela insiste sobre o fato de que este isolamento é, por sua vez, uma atitude pessoal, individual, e ainda um modo, uma forma de governar que provoca, reforça, desenvolve e redobra o sentimento de humilhação: o autoritarismo sem limites, a coerência perfeita, a integridade sem falhas irão aparecer como marcas de competência, de capacidade, de profissionalismo, contribuindo para definir uma forma específica de tirania, de perseguição e de absolutização que, sem sofrer alguma exceção, irão tornar-se "a atitude de todos os membros da administração britânica.”. ${ }^{20}$

Arendt evoca, a seguir, o clima geral propício à arrogância, a partir do qual se desenvolve o pensamento racial na Alemanha, as formas grandiosas de representação de si e de desprezo do outro: " essa insistência sobre uma origem tribal comum como condição essencial da identidade nacional”, formulada pelos nacionalistas alemães durante e após a guerra de 1914. Ela lembra, por outro lado, que o "acento colocado pelos românticos sobre a personalidade inata e a nobreza natural prepararam intelectualmente o terreno para o pensamento racial na Alemanha.,21

\subsection{A Arrogância do Isolamento}

Arendt distingue diferentes níveis de humilhação: ela observa, em primeiro lugar, a dos "homens supérfluos ....que se descompensam, eles não abandonaram a sociedade, mas foram rejeitados por ela."22 Ela distingue uma outra forma de humilhação nas origens do pensamento racial, uma humilhação nascida da apreensão, do medo, às vezes fóbico, do pânico face à alteridade radical.

\footnotetext{
${ }^{18}$ Ibid., p.154.

${ }^{19}$ C. Haroche. Governar-se, governar os outros. (Elementos de uma antropologia política dos costumes e das maneiras dos sécs. XVI-XVII). IN: Communications, 1993.

${ }^{20}$ Hanna Arendt, nota 6, supra-citada, p.154.

${ }^{21}$ Ibid., p.88-89. Ver também G. Mosse (1997). A imagem do homem. A invenção da virilidade moderna. Convém observar aqui também que com o ego grandioso trata-se da questão do narcisismo que Arendt não aborda, entretanto, em seus escritos.

${ }^{22}$ Ibid., p.35.
} 
A denominação da raça e seu prolongamento na colonização constituíram formas de opressão mais insidiosas, mais dissimuladas e mais hábeis que a escravidão, observa Arendt, que viriam a assegurar a continuação da escravidão, uma colonização interior, psíquica:

Esse medo de qualquer coisa que se assemelha e que não deveria, todavia, ser semelhante em qualquer caso permanece ligado ao próprio princípio da escravidão $e$ antecipa o fundamento de uma sociedade de raças. ${ }^{23}$

Arendt julga esta atitude de arrogância e de enorme desapego mais alarmante, pois ela supõe a impossibilidade de se identificar: ela conduz à distância absoluta para se proteger do outro; instaura um afastamento maximamente antecipado, evita, suprime toda possibilidade de identificação, conduzindo, assim, à inexistência, ao não-valor, ao apagamento completo do outro. É preciso ver nesta distância, na impossibilidade de identificação, um verdadeiro sistema que se define pela recusa da exceção, uma rigidez, uma atitude implacável, cruel, na medida em que ela recusa toda divagação, toda falha, todo erro, toda vulnerabilidade. Esta atitude revela o ódio da falha, do outro, do diferente, do estrangeiro.

Ela percebe uma forma de governo mais perigosa que o despotismo e o arbitrário, porque ela não tolera nem mesmo este último laço entre um déspota e seus súditos, feito de desonestidades e de presentes. $^{25}$ Assim, ela discerne também o sentimento de superioridade, o caráter ameaçador, de modo eminente, à ação neste tipo de narcisismo:

A própria integridade da administração britânica tornou seu governo despótico mais desumano e mais inacessível a seus súditos que não teriam sido jamais nem os chefes asiáticos, nem os cruéis conquistadores. Integridade e desapego foram o s símbolos de uma divisão absoluta de interesses até o ponto em que não iriam opor-se mais. A título de comparação, a exploração, a opressão e a corrupção desempenham o papel de “ muralhas da dignidade humana,” pois explorador e explorado, opressor e oprimido... vivem ainda no mesmo universo....,26

Arendt destaca, então, o componente automático, mecânico que funda o sentimento de pertencer ao grupo, o narcisismo grupal que opera nessas formas de comportamento do administrador insensível.

\footnotetext{
${ }^{23}$ Ibid., p.122. Ver Elke Winter sobre essas questões. O debate sobre 'raça e sociedade' no Primeiro Congresso da Sociedade Alemã de Sociologia (1910) re-publicado em "Max Weber e as relações étnicas. Da rejeição do biologismo racial ao Estado multinacional (2004). Arendt lembra, assim, que "os africanders ( colonizadores holandeses na África do Sul) não podem jamais esquecer seu primeiro e terrível sentimento diante de um tipo de homem que seu orgulho... impediu de aceitar como seu semelhante.” (p.122); “em seu terror e sua miséria os africanders resolveram explorar esses selvagens como se eles representassem não a vida humana, mas uma forma de vida animal.” (p.126) “As diferenças que lhes eram atribuídas em relação aos outros povos não remetia à cor de sua pele, mas ao fato de que eles se comportavam como parte integrante da natureza, que tratavam a natureza como mestre incontestado, que eles não tinham criado um mundo humano, uma realidade humana e que a natureza, para eles, seria por conseqüência, vivida de forma majestosa como a única realidade possível (...). Seriam, se podemos dizer, seres humanos "naturais”, aos quais faltava o caráter especificamente humano, a realidade especificamente humana, a tal ponto que quando os europeus os massacraram, ele não tinham, no fundo, consciência de ter cometido homicídio.” (p.123).

${ }_{25}$ Ibid., p. 154-155. Ver também H. Arendt (1997) Eichman em Jerusalém. "Considerações Sobre a Banalidade do Mal “ e sistema totalitário em “As origens do Totalitarismo”, nota supra-citada 6.

${ }^{26}$ Ibid., p.155. Ver E. Balibar. Volência: idealismo e crueldade. In: F. Heritier (1996), De la Violence (Seminaire).
} 
“..... também ao invés de crer em sua superioridade pessoal com um pouco de vaidade inofensiva, ele possuía, sobretudo, o sentimento de pertencer a uma nação que havia atingido um nível de civilização bem mais elevado.” ${ }^{27}$

Dedicando-se a considerações gerais sobre o problema da colonização e sem jamais dize-lo de modo aberto, Arendt apresenta assim, implicitamente, uma descrição que surpreende acerca da psicologia dos colonizadores ingleses, dos burocratas, dos administradores coloniais, de sua violência psíquica.

É interessante, então, prosseguir a reflexão através do estudo consagrado por Memmi ao colonizador e ao colonizado - à colonização em geral, à própria visão de toda colonização.

\section{A DEPENDÊNCIA: UM LAÇO RECÍPROCO REVELADO PELA HUMILHAÇÃO}

Albert Memmi, em 1957, em uma obra dedicada a um "Retrato do Colonizado e do Colonizador" irá, de modo diferente de Arendt, dedicar-se aos mecanismos de humilhação do cotidiano que o colonizador impõe ao colonizado, assinalando que o primeiro, sendo também tomado pelo sentimento de humilhação, deve construir um sistema de defesa, de compensação, para ser temido, respeito e, portanto, para que ele próprio não experimente a humilhação.

Memmi estende sua análise a todas as formas de colonização, engajando-se à elaboração de uma teoria do conjunto da relação colonial e regatando uma psicologia geral da colonização, do colonizador e do colonizado: o sistema colonial aparece, deste modo, como um sistema que engendra um processo de desvalorização que pode remeter da depreciação à anulação do outro.

Ele confia que empreendeu, no prefácio, um inventário da condição do colonizado, "primeiramente para compreender a mim mesmo e identificar meu lugar entre os outros homens." ${ }^{28}$ E constata que "todos os colonizados se assemelham”, observando também que "todos os oprimidos se assemelham em alguma medida." Memmi descobre, então, que " a relação colonial ...encadeava o colonizador e o colonizado em uma espécie de dependência implacável. ${ }^{29}$ Ele irá, deste modo, explicitar o caráter ambíguo e às vezes profundamente contraditório das condutas e disposições psicológicas do colonizador e do colonizado:

como podia o colonizador cuidar de seus operários e ao mesmo tempo metralhar periodicamente uma multidão colonizada? Como o colonizado podia se rejeitar tão cruelmente e ao mesmo tempo reivindicar de uma maneira tão excessiva? Como ele podia detestar e simultaneamente admirar o colonizador de modo passional? ${ }^{30}$

Memmi pretende assim dedicar-se à descrição, simples mas rigorosa (...), de suas misérias, de sua humilhação e de sua condição objetiva de opressão” e mais ainda, sua condição subjetiva: a condição objetiva da subjetividade do oprimido, o fato colonial é uma

\footnotetext{
${ }^{27}$ Ibid.

${ }^{28}$ Memmi, prefácio, nota supra-citada 6, p.12.

${ }^{29}$ Ibid.p.13

${ }^{30}$ Ibid. P.13-14.
} 
condição objetiva e indissociavelmente subjetiva que se impõe aos dois parceiros da colonização. ${ }^{31}$

\subsection{O Privilégio da Superioridade do Colonizador}

Ele dá destaque , assim, a uma noção de privilégio, central na colonização. Esta noção não é abordada de acordo com sua significação jurídica; se o privilégio do colonizador é constituído pelo conjunto de direitos específicos, os quais ele coloca ao dispor do colonizado, é notadamente para materializar a distância que ele deve observar, por sua perspectiva. O privilégio retido por Memmi é essencialmente de função econômica, reconhecendo, entretanto, que a "humilhação cotidiana do colonizado e seu esmagamento objetivo não são somente de ordem econômica; o triunfo permanente do colonizador não é somente econômico." Memmi fala, então, de privilégio "subjetivo, psicológico."

O pequeno colonizador, o colonizador pobre acreditava em si mesmo e em um sentido era realmente superior ao colonizado, objetivamente, e não somente em sua imaginação. E isso fazia igualmente parte do privilégio colonial. ${ }^{32}$

Sartre, no prefácio dessa obra, destacará, assim, à semelhança de Hanna Arendt, a estreiteza do laço, o caráter indissociável da colonização e o racismo.

O racismo é... engendrado... pelo aparelho colonial, sustentado por relações de produção que definem duas espécies de indivíduos: o privilégio e a humanidade que fazem um (...); para o outro, a ausência de direito sanciona sua miséria, sua fome crônica, sua ignorância, em síntese, sua sub-humanidade. ${ }^{33}$

Esforçando-se para descrever os processos e as modalidades da colonização governados por exigências paradoxais, Memmi dedica-se a estudar as atitudes do colonizador e do colonizado; ele se centra em torno da subjetividade, da afetividade, indicando que o colonialista tem necessidade da existência do colonizado e da anulação do outro (...), de negar o colonizado e , ao mesmo tempo, a existência de sua vítima é indispensável para continuar a ser. ${ }^{34}$ Ele observa, então, que "esta dependência do

\footnotetext{
${ }^{31}$ Ibid., p.14.

32 Ibid., p.16. O que conduziu Memmi a observar que “ se os Negros, na América do Norte, são mais maltratados que os operários brancos, não é porque eles se relacionam mais desta maneira: este cálculo se reverá falso se o pusermos em termos de economia. Na realidade, eles são maltratados porque são tratados “em negro”, isto é, de um modo, justamente, que a economia não pode descrever com seus conceitos. O “colonial” não persegue somente um lucro. Ele busca também, avidamente, certas satisfações psicológicas. ( O MANNONI, nota supra-citada 3, p.40-41).

${ }^{33}$ SARTRE, prefácio a MEMMI, nota supra-citada 6, p.23-24. Ver MEMMI, nota 6, p.72: “... o pequeno colonizador é, de fato, solidário com os colonos e defensor ferrenho dos privilégios coloniais. Por quê? Solidariedade do semelhante com o semelhante? Reação de defesa? Expressão ansiosa de uma minoria viva no meio de uma maioria hostil? Em parte. Se o pequeno colonizador defende o sistema colonial com tanto apreço, é porque ele é pouco ou muito beneficiado." Sobre essas questões ver REICH "Psychoçogie de masse du fascisme” (1933), Paris, Payot, 1998. N. ELIAS, The Germans (1989), Polity Press, 1996. Ver igualmente sobre essas duas espécies de indivíduos nas sociedades individuaistas contemporâneas, R. CASTEL, CL. HAROCHE, nota supra-citada 4.

${ }^{34}$ MEMMI, nota supra-citada 6, p.75. Memmi enfatiza assim - sem ambigüidade a respeito do que ele entende por este termo - o medíocre, do ponto de vista das aspirações intelectuais, dos valores, das
} 
colonizador em relação ao colonizado enche o primeiro de ódio, uma vez que ele se vê condenado a reconhecer, como permanente, a necessidade daquilo que ele exerce com aplicação.

"O colonialista se dá conta de que sem o colonizado a colônia não teria nenhum sentido. Esta contradição insuportável toma-o de fúria, de um ódio sempre pronto a se desencadear sobre o colonizador., 35

\subsection{A Representação do Colonizado Sem Individualidade}

Memmi irá, como Arendt, enfatizar o papel da distância que a colonização coloca entre o colonizador e o colonizado, e nesta enunciação ele irá dar destaque ao papel e à função que a metrópole desempenha: condição de valor, da valorização do colonizador, legitimando-o a assegurar a distância espacial; vigor de uma missão civilizadora reconhecida por seu direito, a metrópole possui, nessa esfera de relações face a face entre colonizador e colonizado, uma função psíquica, psicológica, social e política. Ela autoriza o desprezo, institui a inferioridade do colonizado - pelo código do indigenato - e mesmo para além deste código - esta inferioridade é reforçada pelo afastamento, pela distância, por atitudes e sentimentos de superioridade.

“.... a metrópole não é tão grande porque ela está além do horizonte e porque ela permite valorizar a existência e a conduta do colonialista; se ele retornasse......deixaria de ser um homem superior: se tudo está na colônia, o colonialista sabe que na metrópole ele não será nada. Ele voltaria a ser um homem qualquer. De fato... a noção de metrópole...reportada a ela mesma, perderia o sentido e arruinaria a um só golpe a condição superior do colonialista. É somente na colônia, porque ele possui uma metrópole e seus co-habitantes não, que o colonialista é temido e admirado ${ }^{36}$.”

Memmi detalha, então, a desvalorização sistemática que o colonizador atribui ao colonizado: "seu país que é feio, demasiado quente.... mal cheiroso.” Ele é profuso em termos de "comparações morais ou sociológicas, estéticas ou geográficas, explícitas, insultantes ou alusivas e discretas, mas sempre em favor da metrópole e do colonialista. Aqui, as pessoas nativas, os costumes do país são sempre inferiores, e distantes, em conseqüência de uma ordem fatal e pré-estabelecida." O colonialista é, deste modo, conduzido a enclausurar o colonizado na alteridade, em sua identidade, congelando-o, imobilizando-o Ele fala da natureza do colonizado - fazendo Arendt pensar novamente -: o colonizador é livre, ele toma as iniciativas, é um homem de ação, ele privilegia o movimento, possui a experiência, ele é concreto, sólido, forte, tenaz, determinado; ele conhece o terreno, é hostil à teoria, desconfia das idéias, por definição, abstratas, gerais. Memmi dá ênfase, assim, à desconfiança do colonizador ao direito de toda discussão, reflexão, hesitação, interrogação, tendo que ".a duras penas construir seu sistema de compensação ${ }^{37}$.”. Ele não tem ou não pretende mostrar senão certezas.

representações de si e dos outros: “é o medíocre que impõe o tom geral da colônia. É ele que é o verdadeiro parceiro do colonizado, pois é ele que tem a maior necessidade de compensação e da vida colonial. É entre ele e o colonizado que se criam as relações coloniais mais típicas.” (ide.p.72)

${ }^{35}$ Ibid., p.86.

${ }^{36}$ Ibid., p.81.

${ }^{37}$ Ibid., p.87,89. 
O colonizador congela o colonizado, seqüestra-o em uma identidade imutável, “aquilo que o colonizado é verdadeiramente”, "um indivíduo singular, original, particular, insubstituível, pouco importa ao colonizador...que recusa observar os acontecimentos pessoais, particulares da vida do colonizado: esta vida em sua especificidade não lhe interessa." O colonizador instrumentaliza, portanto, o colonizado. "Ao colonizado não se pede além dos braços e ele é só isso" 38 , ele é julgado como desprovido de pensamento, de saber, de competência; em síntese, privando o colonizado de atributos, de qualidades e de direitos humanos, ele o desumaniza.

Longe de querer apreender o colonizado em sua própria realidade, o colonizador está "preocupado em faze-lo suportar esta indispensável transformação". Memmi nota, assim, que o colonizado não é descrito de modo positivo, "ele consiste, antes de mais nada, em uma série de negações”: jamais é considerado positivamente, ou se é, a qualidade concedida releva uma falta psicológica ou ética ${ }^{39}$.

Ele observa a relação do colonizado que se esforça por "superar o desprezo e manifesta "sua submissão admirativa" e que talvez, vivenciando a influência de políticas assimilatórias adotadas nas colônias francesas - testemunhe "sua preocupação voltada a confundir-se com o colonizador, a trajar-se como ele, a falar e se conduzir como ele." O colonizado tenta, deste modo, tornar-se outro, conquistar todas as suas dimensões, as quais o colonizador amputou (...) em nome daquilo que ele deseja; ele é incitado a empobrecerse, a extorquir a si próprio.", ${ }^{40}$

O colonizado se caracteriza por sua impulsividade e imprevisibilidade. A impossibilidade de prever a seu respeito anuncia uma outra dificuldade, a de conhece-lo: ele é diferente do colonizador, de uma diferença muitas vezes inapreensível; mais importante, todavia, que o caráter incompreensível desta diferença é que ele é semelhante aos outros em sua comunidade, em seu povo.

Uma vez que ele não é um indivíduo singular, não é uma pessoa, ele parece não ter história e personalidade individual; ele não se distingue nem do grupo, nem do coletivo, não tem direitos, conforme observa Memmi "que no núcleo do coletivo anônimo (eles são isto, são todos o mesmo.)" ${ }^{\text {"41 }}$ Sem ter de levar em conta o fato de que estas percepções são aquelas dadas pelo direito colonial então em vigor, chegamos, assim, à constatação de que ele é indiferenciado.

Memmi discerne no colonizado uma diferença não-assimilável, e percebe a indiferenciação como a condição coletiva e anônima do indígena, o que o leva a concluir que "o colonizado... não é o homem portador de valores universais, em geral, comum a todos os outros homens (...)”Nós o repelimos com desprezo em relação àquilo que nele seria não assimilável pelos outros.”,

Memmi convida, então, a uma interrogação sobre o estatuto do colonizado " o que pode restar-lhe em termos deste esforço de desnaturalização?”... é ainda tão só um ser

\footnotetext{
${ }^{38}$ Ibid.,p.100,103.

${ }^{39}$ Ibid.,p.103.

${ }^{40}$ Ibid., p.136,139,140.

${ }^{41}$ Ibid, p.104.

${ }^{42}$ Ibid. p.147. Eric Savarese (1998:14-16), engajado recentemente ao estudo da abolição da alteridade: A ordem colonial e sua legitimação na França metropolitana. Ele observa, deste modo, “a usura progressiva da diversidade no discurso colonial conduzido à indiferenciação (...) através de uma censura da alteridade, o lento desaparecimento dos indígenas.”
} 
humano. Ele tende rapidamente para o objeto. ${ }^{43} \mathrm{E}$ o autor conclui, enfim, que a exclusão, e deste fato, a enfermidade identitária na comunidade, seja também artificial às vezes, já que ela tem sido construída geralmente, em todas as peças, pelo direito do Estado colonizador a imobilidade do passado, do presente e do futuro são as faltas mais graves de que sofre o colonizado " a carência mais grave vivida pelo colonizado é de estar fora da história e fora da cidade.” 44

O colonizado é, pouco a pouco, reduzido ao estatuto de objeto ou apreendido indistintamente na massa: as diferenças não exprimem a singularidade do indivíduo que ele é inegavelmente; elas contribuem para massifica-lo; supõem e conduzem a uma indiferenciação profunda entre indivíduos: "os indígenas são às vezes assemelhados em uma categoria genérica e totalizante sem relação a qualquer particularidade com o próprio indígena., 45

\subsection{Colonização do Outro, Colonização de Si, Colonização Interior}

Reportem-nos, novamente, ao enunciado de Weber prognosticando o caráter crucial das relações comunitárias nas sociedades contemporâneas: “ o estudo das relações de atração e de repulsão entre diferentes comunidades étnicas não está, atualmente, senão em seu começo;" este enunciado soa, com efeito, como uma advertência, uma imbricação extraordinariamente complexa entre os fatores econômicos, raciais e burocráticos: a arrogância, que supõe a maestria de si, o desdém e até a denegação do outro, é o que incita a refletir sobre o que os administradores coloniais têm de comum, de idêntico com os gestores, os administradores, os burocratas contemporâneos. ${ }^{46}$

É preciso, talvez, encarregar-se de interrogações a partir da análise da situação colonial histórica e política, em sentido estrito, sobre as formas de colonização e de opressão insidiosas e difusas, sem colonizador visível. Trata-se de formas inéditas de alienação e de ausência da posse de si, dos indivíduos para os quais o sentimento de humilhação é reforçado, mas, ao mesmo tempo, entendido, diluído e, às vezes, indiscernível em sua especificidade. As fronteiras visíveis entre espaços, territórios produzem mais enfermidades, mas ao mesmo tempo podem proteger os indivíduos, os grupos. A colonização adquire, atualmente, outras formas: a colonização interior, psíquica, é multiplicada na mundialização, com ausência de fronteiras interiores e exteriores, com a emergência de uma reflexividade contínua, conduzindo a uma enfermidade paradoxal no ser. Estes efeitos psíquicos, remetendo a uma colonização interior, se traduzem por um empobrecimento, um estreitamento interior e tendem, assim, a apresentar os elementos de estatuto de colonizado, estendendo ou apagando, generalizando as formas anteriores de colonização. ${ }^{47}$

Através da réplica de um artigo pioneiro, publicado em 1951, sobre a situação colonial, Balandier foi recentemente interrogado sobre o fato de saber se "a ferramenta intelectual que é a noção de situação colonial, com a teorização que a precede tornou-se

\footnotetext{
${ }^{43}$ Ibid., p.105.

${ }^{44}$ Ibid., p.111.

${ }^{45}$ Savarese, nota 42, supra-citada.

${ }^{46}$ V.V. DIMIER (2004). O governo das colonias. Olhares cruzados franco-britânicos. Ver igualmente V. de GAULEJAC (2005) A sociedade enferma da gestão.

${ }^{47}$ Ver Claudine Haroche (2008). Processos psicológicos e sociais de humilhação: o empobrecimento do espaço interior.
} 
obsoleta pelo desaparecimento das colonizações oriundas de imperialismos do séc. XIX.” Ele observa a necessidade de partir da constatação de que o "pós-colonial" não é o apagamento do "colonial" mas somente de suas formas mais aparentes ${ }^{48}$. Balandier observa, então, que:

“...aparecem outras formas de relação de manutenção; aquelas que direcionam, em relação aos velhos países colonizadores, os fluxos de imigrantes oriundos das antigas colônias. O pluralismo social e cultural após ter estado do lado de fora das colônias, o produto das conquistas e do estabelecimento dos atores da colonização, constituem-se e se estendem ao próprio interior das metrópoles dos países que se tornaram imperiais. Esse pluralismo interioriza aquilo que sobrevive da relação colonial sob outras formas. Como se esta relação ocupasse ainda as consciências, mas exprimindo-se por meio de outras linguagens e de outras dinâmicas culturais."49

O antropólogo conclui, então, observando que, novamente, para a emergência de "Novos Mundos", onde se estabelecem espécies de colonização "internas”, "em um ou outro caso a noção de situação colonial conserva uma força interpretativa e crítica."

Balandier pergunta, na mesma obra, se "a antropologia ainda é possível”, e lembra que a antropologia, como modo de conhecimento das culturas e das sociedades, tem sido, em primeiro lugar, "a exploração da diversidade", dando ênfase ao fato de que "as formas atuais tomadas pela dinâmica das diferenças (...) parecem mais "embarlhadas", o que vai ao encontro da própria definição de humano: “ nós introduzimos, de modo contínuo, observa ele, a diferença em nós mesmos tendo acesso a ela."

O movimento, a não-limitação territorial constituem as características fundamentais do imperialismo expansionista no século XIX: elas aparecem hoje como um resultado, uma repetição, uma extensão, uma intensificação desta colonização e desta burocracia. O movimento contínuo, a fluidez, a expansão ilimitada do percurso nas sociedades contemporâneas comportam dimensões inéditas, ligadas, entre outras coisas, à extensão da tecnologia, do virtual: entranhando uma denegação geral do limite, da existência do outro nas formas de narcisismo contemporâneo; as novas formas de capitalismo tendem a estruturar os indivíduos em seu interior, incitando-os à arrogância, à indiferença, à insensibilidade e ao desapego.

Tradução: Ana Zandwais (PPG- LET - UFRGS)

\section{REFERÊNCIAS}

ARENDT, Hanna.Les origins du totalitarisme. Paris, Ed. Fayard, 1982. . Rapport sur la banalité du mal. Paris, Folio Gallimard,1997. BALANDIER, G. Cahiers Internacionaux de sociologie. Paris, 1951.

\footnotetext{
${ }^{48}$ BALANDIER, ‘A situação colonial; antiga noção, nova realidade’, nota 3, supra-citada, p.158.

${ }^{49}$ Ibid.

${ }^{50}$ Ibid.,p.159.

${ }^{51}$ BALANDIER, “É ainda possível uma antropologia?” In: Civilisés, dit-on”, nota 3, supra-citada, p.252-257.
} 
BALIBAR, E. Violence: idealité et cruauté. In: HERITER, F. De la violence. Paris, Ed. Odile Jacob, 1966.

BREPHOL, Marion. Arrogância e isolamento na política colonial de Carl Peters. In: Sobre a humilhação: sentimentos, gestos e palavras. Uberlândia, Ed. UFU, 2005.

DIMIER, V. Regards croisés franco-britanniques. Bruxelles, Université libre de Bruxellles, 2004.

ELIAS, Norbert. The Germans. Cambridge, Oxford, Polity Press, 1996.

FREUD, Sigmund. Malaise dans la culture. Paris, Ed. PUF, 1995.

GOFFMAN, E. Stigmates. Paris, Ed. De Minuit, 1975.

. Civilisés, dit on. Paris, Ed. PUF, 2003.

HAROCHE, Claudine. Remarques sur les incertitudes et les ambiguities du droit à la dignité. In: KOUBI, G. Le préambule de la constituition de 1946. Antinomies juridiques et contradictions politiques. Paris, Ed. PUF, 1996.

. Crise da consciência contemporânea e expansão de um saber não acumulativo. In:

História e perspectivas. Uberlândia, Ed. UFU, 2005, p.13-37. Trad. Jacy Alves Seixas. . L'avenir du sensible. Paris, Ed. PUF, 2008.

. A condição sensível. Formas e maneiras de sentir no ocidente. Rio de Janeiro, Ed. Contra Capa, 2008. Trad. Jacy Alves de Seixas e Vera Avellar Ribeiro.

LEVI STRAUSS, C. Race et histoire. Paris, Folio, 2004.

MEMMI, A. Portrait du colonisé. Portrait du colonisateur. Paris, Folio Gallimard, 2002.

NAXARA, Márcia, MARSON, Isabel. Sobre a humilhação: sentimentos, gestos, palavras. Uberlândia, Ed. UFU, 2005.

REICH, W. La psychologie de masse du fascisme. Paris, Ed. Payot, 1998.

STOLER, V.A.L. Carnal knowledge and imperial power. Race and the intimate in colonial rule. California, University California Press, 2002.

WEBER, Max. Économie et societé. Paris, Pocket, 1995. 